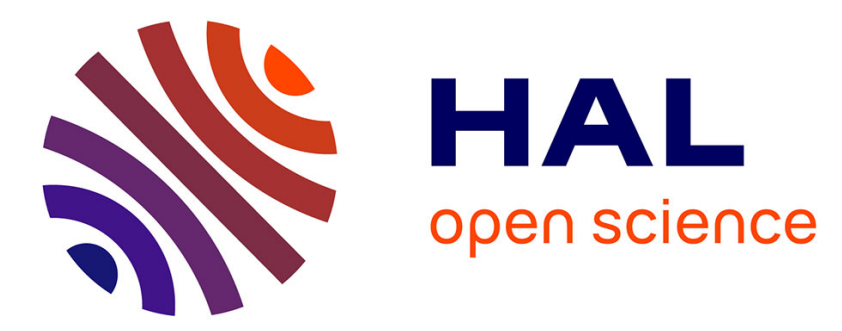

\title{
Toughened carbon nanotube-iron-mullite composites prepared by spark plasma sintering
} Alicia Weibel, Alain Peigney, Geoffroy Chevallier, Claude Estournès, Christophe Laurent

\section{- To cite this version:}

Alicia Weibel, Alain Peigney, Geoffroy Chevallier, Claude Estournès, Christophe Laurent. Toughened carbon nanotube-iron-mullite composites prepared by spark plasma sintering. Ceramics International, 2013, vol. 39, pp. 5513-5519. 10.1016/j.ceramint.2012.12.063 . hal-00864749

\author{
HAL Id: hal-00864749 \\ https://hal.science/hal-00864749
}

Submitted on 23 Sep 2013

HAL is a multi-disciplinary open access archive for the deposit and dissemination of scientific research documents, whether they are published or not. The documents may come from teaching and research institutions in France or abroad, or from public or private research centers.
L'archive ouverte pluridisciplinaire HAL, est destinée au dépôt et à la diffusion de documents scientifiques de niveau recherche, publiés ou non, émanant des établissements d'enseignement et de recherche français ou étrangers, des laboratoires publics ou privés. 


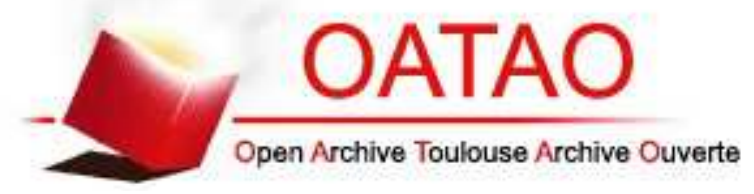

\section{Open Archive TOULOUSE Archive Ouverte (OATAO)}

OATAO is an open access repository that collects the work of Toulouse researchers and makes it freely available over the web where possible.

This is an author-deposited version published in : http://oatao.univ-toulouse.fr/ Eprints ID : 9359

To link to this article : DOI:10.1016/j.ceramint.2012.12.063

URL : http://dx.doi.org/10.1016/j.ceramint.2012.12.063

To cite this version : Weibel, Alicia and Peigney, Alain and Chevallier, Geoffroy and Estournès, Claude and Laurent, Christophe. Toughened carbon nanotube-iron-mullite composites prepared by spark plasma sintering. (2013) Ceramics International, vol. 39 ( $\mathrm{n}^{\circ}$ 5). pp. 5513-5519. ISSN 0272-8842

Any correspondance concerning this service should be sent to the repository administrator: staff-oatao@ listes-diff.inp-toulouse.fr 


\title{
Toughened carbon nanotube-iron-mullite composites prepared by spark plasma sintering
}

\author{
Alicia Weibel, Alain Peigney, Geoffroy Chevallier, Claude Estournès, Christophe Laurent ${ }^{*}$ \\ Université de Toulouse, Institut Carnot CIRIMAT, UPS CNRS, Université Paul-Sabatier, 118 Route de Narbonne, 31062 Toulouse Cedex 9, France
}

\begin{abstract}
Carbon nanotube-iron-mullite nanocomposite powders were prepared by a direct method involving a reduction in $\mathrm{H}_{2}-\mathrm{CH}_{4}$ and without any mechanical mixing step. The carbon nanotubes are mostly double- and few-walled (3-6 walls). Some carbon nanofibers are also observed. The materials were consolidated by spark plasma sintering. Their electrical conductivity is $2.4 \mathrm{~S} / \mathrm{cm}$ whereas pure mullite is insulating. There is no increase in fracture strength, but the SENB toughness is twice than the one for unreinforced mullite (3.3 vs. 1.6 $\mathrm{MPa}{ }^{1 / 2}$ ). The mechanisms of carbon nanotube bundle pullout and large-scale crack-bridging have been evidenced.
\end{abstract}

Keywords: A. Spark plasma sintering; B. Nanocomposites; D. Mullite; D. Carbon nanotubes

\section{Introduction}

Carbon nanotubes (CNTs) show a high aspect ratio and excellent mechanical, electrical and thermal properties. For example, a Young's modulus close to $1 \mathrm{TPa}$ [1] and a tensile strength up to $60 \mathrm{GPa}$ [2] have been reported. For multi-walled CNTS (MWCNTs), an electrical conductivity higher than $10^{5} \mathrm{~S} / \mathrm{m}$ [3] and a thermal conductivity higher than $3000 \mathrm{~W} / \mathrm{mK}$ [4] have been reported. Therefore, ceramic-matrix composites containing CNTs have been increasingly studied for about fifteen years as revealed by recent reviews of the field $[5,6]$. In particular, toughening is intensively researched. It is important to note that the presence of CNTs induces changes in the kinetics and mechanisms of sintering [7], which can greatly modify the matrix microstructure [8] and may in turn have a greater effect on the properties than the actual presence of CNTs $[9,10]$. Mullite is the name of some $\mathrm{Al}_{2} \mathrm{O}_{3}-\mathrm{SiO}_{2}$ compounds. The most widely studied form is $\mathrm{Al}_{6} \mathrm{Si}_{2} \mathrm{O}_{13}$ (also commonly designated $3 \mathrm{Al}_{2} \mathrm{O}_{3}: 2 \mathrm{SiO}_{2}$ ), an important material for electronic, optical and high-temperature structural applications, which are however limited by a low toughness [11].

\footnotetext{
${ }^{*}$ Corresponding author. Tel.: +33561556122; fax: + 33561556163 .

E-mail address: laurent@chimie.ups-tlse.fr (C. Laurent).
}

Nevertheless, CNT-mullite composites are seldom studied. Wang et al. [12] prepared such materials by mixing powders of multi-walled CNTs (MWCNTs), $\mathrm{Al}_{2} \mathrm{O}_{3}$ and $\mathrm{SiO}_{2}$, followed by hot-pressing in argon. These authors reported a moderate increase in bending strength and a strong increase in toughness, compared with pure mullite. Fracture of MWNTs and pullout of MWNTs at interfaces were proposed as reinforcement mechanisms. In the present work, CNT-Fe-mullite composites are prepared by an in situ catalytic chemical vapor deposition (CCVD) route [13], without any mixing or milling, thus avoiding any damage to the CNTs at this step. The powders are consolidated by spark plasma sintering (SPS), which requires lower temperatures and shorter times than hot-pressing. The mechanical properties and electrical conductivity are investigated.

\section{Material and methods}

\subsection{Powder synthesis}

The synthesis of the mullite and CNT-Fe-mullite composite powders was reported elsewhere [13]. Mullite $\left(\mathrm{Al}_{6} \mathrm{Si}_{2} \mathrm{O}_{13}\right)$ and iron-substituted mullite $\left(\mathrm{Fe}_{0.6} \mathrm{Al}_{5.4} \mathrm{Si}_{2} \mathrm{O}_{13}\right)$ powders were prepared by a combustion method. The required proportions of $\mathrm{Al}\left(\mathrm{NO}_{3}\right)_{3} \cdot 9 \mathrm{H}_{2} \mathrm{O}, \mathrm{Fe}\left(\mathrm{NO}_{3}\right)_{3} \cdot 9 \mathrm{H}_{2} \mathrm{O}$ and $\mathrm{NH}_{4} \mathrm{NO}_{3}(5 / 6$ of 
the molar quantity of the metal nitrates) were dissolved in an aqueous suspension of colloidal $\mathrm{SiO}_{2}$, using the minimum amount of water. The required proportion of urea (the fuel) was added under continuous stirring up to complete dissolution. The urea proportion was double than the one necessary to reach the so-called stoichiometric ratio calculated from the total oxidizing valence of the nitrates and the reducing valence of urea [14]. The dish containing the mixture was placed in a furnace preheated at $600{ }^{\circ} \mathrm{C}$, keeping the door of the furnace open. After water evaporation, a combustion reaction takes place between the nitrates and urea, thus producing an oxide powder. The as-prepared mullite powder was calcined in air at $1200{ }^{\circ} \mathrm{C}$ and the as-prepared $\mathrm{Fe}_{0.6} \mathrm{Al}_{5.4} \mathrm{Si}_{2} \mathrm{O}_{13}$ powder was divided into two batches, which were calcined in air at 1000 and $1100{ }^{\circ} \mathrm{C}$, respectively (heating rate $300^{\circ} \mathrm{C} / \mathrm{h}, 1 \mathrm{~h}$ dwell, natural cooling), producing powders with a different specific surface areas (4.5 and $2.6 \mathrm{~m}^{2} / \mathrm{g}$, respectively). The so-obtained $\mathrm{Fe}_{0.6} \mathrm{Al}_{5.4} \mathrm{Si}_{2} \mathrm{O}_{13}$ powders were CCVD treated in $\mathrm{H}_{2}-\mathrm{CH}_{4}$ (20 $\mathrm{mol} \% \mathrm{CH}_{4}$, maximum temperature $1050{ }^{\circ} \mathrm{C}$, no dwell, heating and cooling rates $300{ }^{\circ} \mathrm{C} / \mathrm{h}$ ), in order to prepare the CNT-Fe-mullite composite powders. The flowing gas was dried on $\mathrm{P}_{2} \mathrm{O}_{5}$. Its composition and flow $(15 \mathrm{~L} / \mathrm{min})$ were monitored using massflow controllers. The so-obtained powders are designated $\mathrm{C} 1000 \mathrm{R}$ and $\mathrm{C} 1100 \mathrm{R}$ hereafter.

\subsection{Spark plasma sintering}

The powders were consolidated by SPS (Dr Sinter 2080, SPS Syntex Inc., Japan). Samples were loaded into a $20 \mathrm{~mm}$ inner-diameter graphite die. A sheet of graphitic paper was placed between the punch and the powder as well as between the die and the powder for easy removal. The powders were sintered under vacuum (residual cell pressure $<3 \mathrm{~Pa}$ ). A pulse configuration of 12 pulses (one pulse duration $3.3 \mathrm{~ms}$ ) followed by 2 periods $(6.6 \mathrm{~ms})$ of zero current was used. Heating rates of $150{ }^{\circ} \mathrm{C} / \mathrm{min}$ and $100{ }^{\circ} \mathrm{C} / \mathrm{min}$ were used from room temperature to $600{ }^{\circ} \mathrm{C}$ and from 600 to $1500{ }^{\circ} \mathrm{C}$, respectively. A 5 min dwell was applied at $1500{ }^{\circ} \mathrm{C}$. An optical pyrometer, focused on a little hole at the surface of the die, was used to measure the temperature. A uniaxial load (corresponding to a uniaxial pressure of $150 \mathrm{MPa}$ ) was applied from $600^{\circ} \mathrm{C}$ upwards and maintained during the dwell. Natural cooling was applied down to room temperature. The uniaxial pressure was gradually released during cooling. The final sintered specimens were in the form of pellets $20 \mathrm{~mm}$ in diameter and $2 \mathrm{~mm}$ thick.

\subsection{Characterization}

The carbon content in the powders was determined by flash combustion with a relative accuracy of $2 \%$. The specific surface area was measured by the BET method using $\mathrm{N}_{2}$ adsorption at liquid- $\mathrm{N}_{2}$ temperature (Micromeritics FlowSorb II 2300). The reproducibility of the results is $\pm 3 \%$. The sintered pellets were polished with a diamond paste up to $1 \mu \mathrm{m}$. The density of the pellets was measured by the Archimedes method. X-ray diffraction (XRD) patterns were recorded using a Bruker D4 Endeavor diffractrometer equipped with a $\mathrm{Cu} \mathrm{K} \mathrm{K}_{\alpha}$ radiation tube. The powders and sintered specimens were observed by field-emission-gun scanning electron microscopy (FESEM,
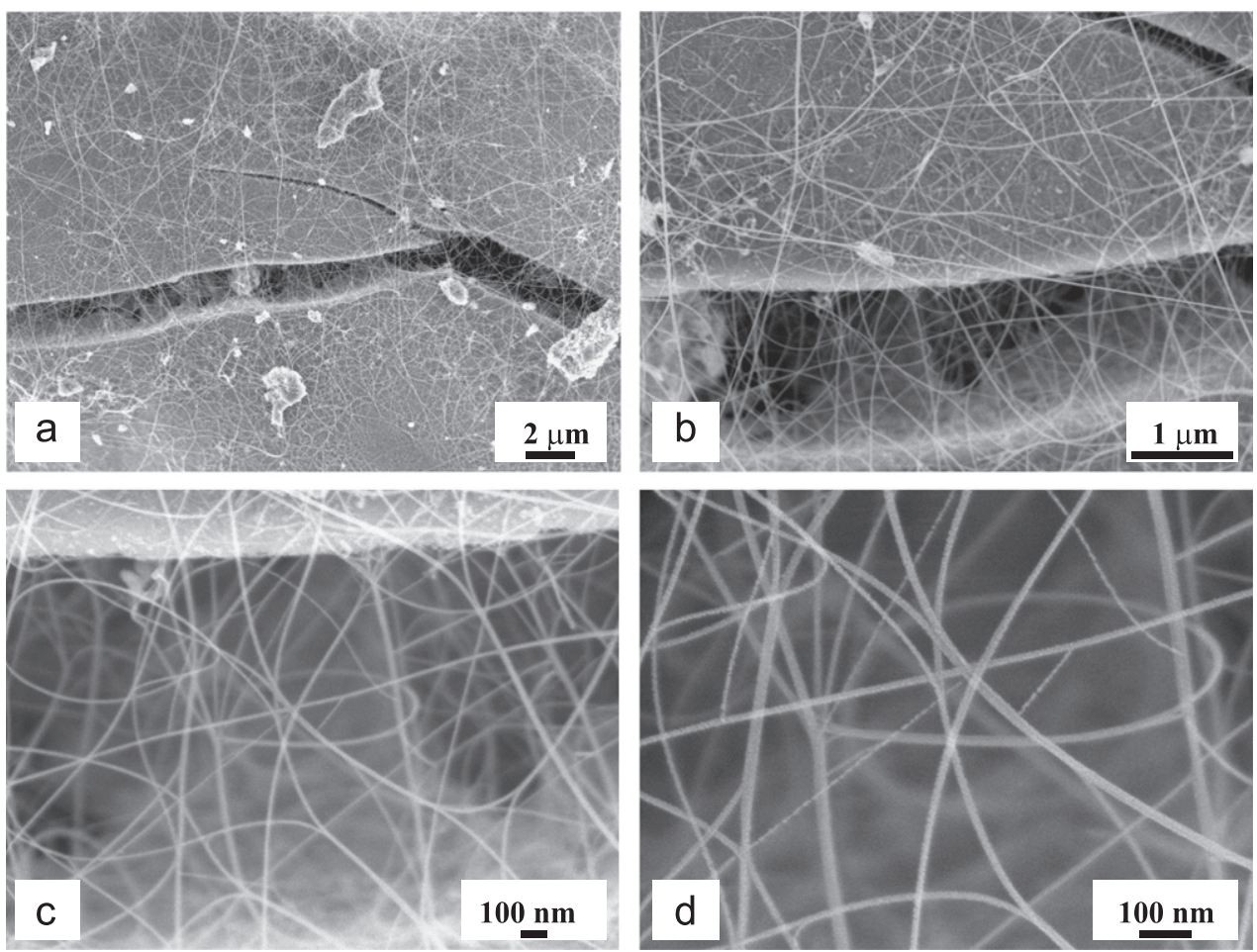

Fig. 1. FESEM images (at an increasing magnification of the same area) of the C1000R CNT-Fe-mullite powder. 

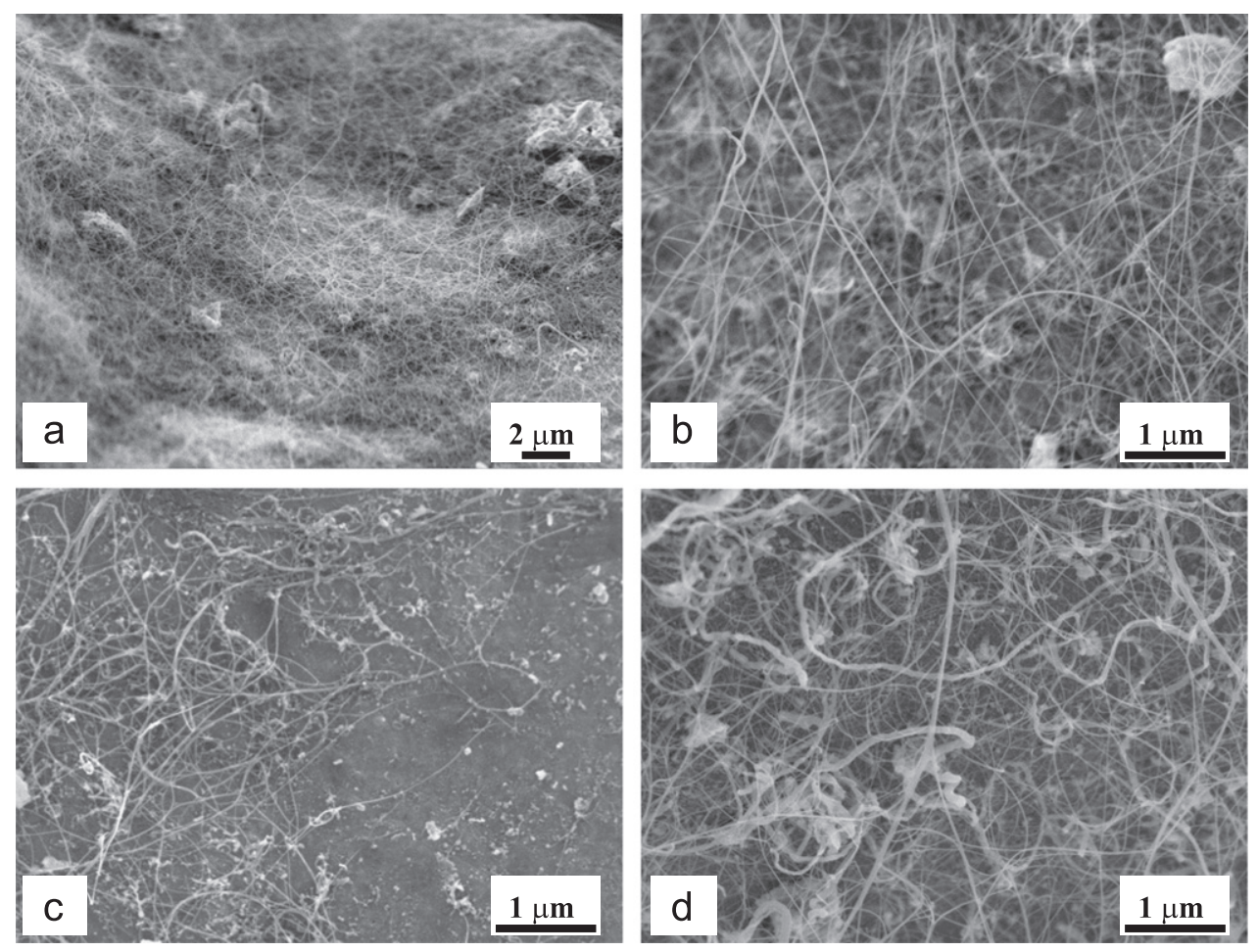

Fig. 2. FESEM images of the $\mathrm{C} 1100 \mathrm{R} \mathrm{CNT}-\mathrm{Fe}-$ mullite powder.

JEOL JSM 6700F). The electrical conductivity was measured at room temperature with d.c. currents on parallelepipedic specimens $\left(1.6 \times 1.6 \times 8 \mathrm{~mm}^{3}\right)$, parallel to their length, i.e. perpendicular to the pressing axis. The current densities used were lower than $160 \mathrm{~mA} / \mathrm{cm}^{2}$ (Keithley 2400). The indentation tests were performed $(5 \mathrm{~N}$ for $10 \mathrm{~s}$ in air at room temperature) on the polished surface of the specimens by loading with a Vickers indenter (Shimadzu HMV 2000). The corresponding diagonals of the indentation were measured using an optical microscope attached to the indenter. The fracture strength was measured by the three-point bending method on specimens about $1.6 \times 1.6 \times 18 \mathrm{~mm}^{3}$ machined with a diamond saw. Cross-head speed was fixed at $0.1 \mathrm{~mm} / \mathrm{min}$. The toughness $\left(K_{\mathrm{Ic}}\right)$ was calculated from three-point bending results on notched specimens (single-edge notch beam, SENB) using a calibration factor [15]. A notch slightly less than half the thickness of the specimen was made using a $100 \mu \mathrm{m}$ diameter $\mathrm{SiC}$ wire.

\section{Results and discussion}

\subsection{Powders}

The formation of the CNT-Fe-mullite powders (C1000R and C1100R) by the CCVD treatment of $\mathrm{Fe}_{0.6} \mathrm{Al}_{5.4} \mathrm{Si}_{2} \mathrm{O}_{13}$ was studied in detail elsewhere [13]. The composition and microstructure of the powders are fairly complex. Indeed, corundum $\left(\alpha-\mathrm{Al}_{2} \mathrm{O}_{3}\right)$, hercynite $\left(\mathrm{FeAl}_{2} \mathrm{O}_{4}\right)$ and $\alpha$-Fe peaks are detected on the XRD patterns in addition to mullite peaks. Moreover, analysis of ${ }^{57} \mathrm{Fe}$ Mössbauer spectra revealed that $\gamma-\mathrm{Fe} / \mathrm{C}$ (a $\gamma-\mathrm{Fe}$

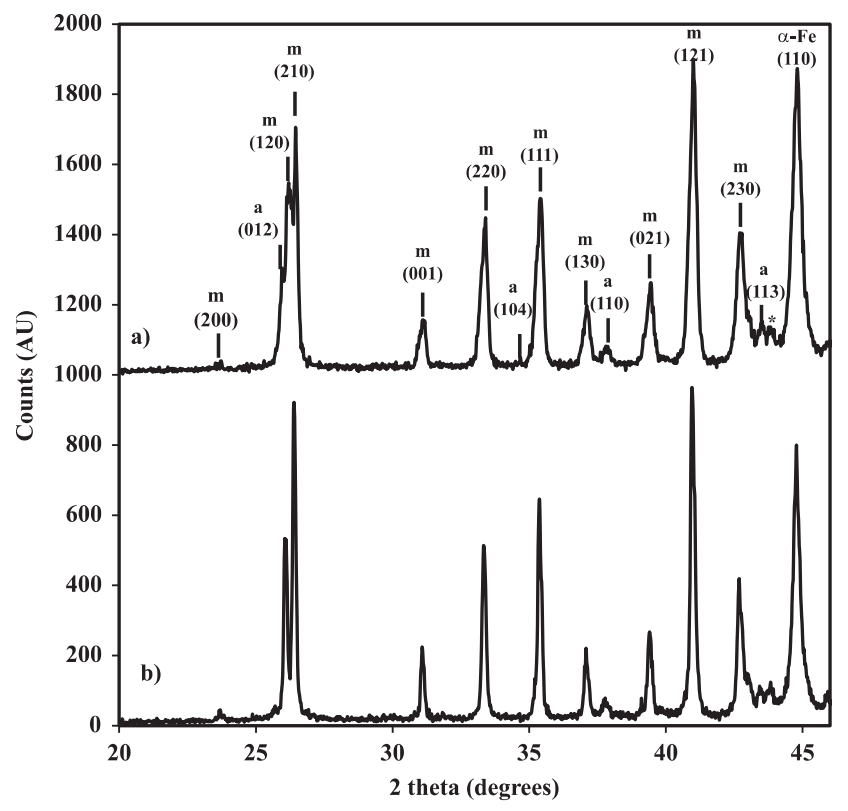

Fig. 3. XRD patterns of the C1000RS (a) and C1100RS (b) CNT-Femullite specimens prepared by SPS. m: mullite; a: $\alpha-\mathrm{Al}_{2} \mathrm{O}_{3} ;{ }^{*}$ : unidentified peak.

phase alloyed with carbon) and $\mathrm{Fe}_{3} \mathrm{C}$ (cementite) are also present but in quantities small enough to remain undetected by XRD. Indeed, the proportions of $\alpha-\mathrm{Fe}, \gamma-\mathrm{Fe} / \mathrm{C}$ and $\mathrm{Fe}_{3} \mathrm{C}$ (about 40,5 and $10 \%$ of all iron phases, respectively) show that slightly more than half the iron ions have been reduced. Thus, the content of reduced phases $\left(\alpha-\mathrm{Fe}, \gamma-\mathrm{Fe} / \mathrm{C}\right.$ and $\left.\mathrm{Fe}_{3} \mathrm{C}\right)$ in the material is 
Table 1

Characteristics and properties of the materials prepared by SPS. $C_{\mathrm{n}}$ : carbon content; $\rho$ : density; HV: Vickers microhardness, $\sigma_{\mathrm{f}}$ : fracture strength; $K_{\mathrm{Ic}}$ : SENB toughness; $\sigma$ : electrical conductivity.

\begin{tabular}{|c|c|c|c|c|c|c|}
\hline & $C_{\mathrm{n}}\left(\mathrm{wt}^{\circ} \%\right)$ & $\rho\left(\mathrm{g} \mathrm{cm}^{-3}\right)$ & HV (GPa) & $\sigma_{\mathrm{f}}(\mathbf{M P a})$ & $K_{\mathrm{Ic}}\left(\mathrm{MPa} \mathrm{m}^{1 / 2}\right)$ & $\sigma(\mathbf{S} / \mathbf{c m})$ \\
\hline Mullite & 0 & 3.09 & 15.1 & 238 & 1.6 & $-^{\mathrm{a}}$ \\
\hline C1000RS & 2.2 & 3.20 & 14.2 & 248 & 3.3 & 2.4 \\
\hline C1100RS & 3.0 & 3.16 & 13.5 & 240 & 2.8 & 2.4 \\
\hline
\end{tabular}

${ }^{\mathrm{a}}$ The electrical conductivity of the mullite pellet is lower than $10^{-13} \mathrm{~S} / \mathrm{cm}$ but cannot be given with precision, because the measured resistance value was the detection limit of the equipment.
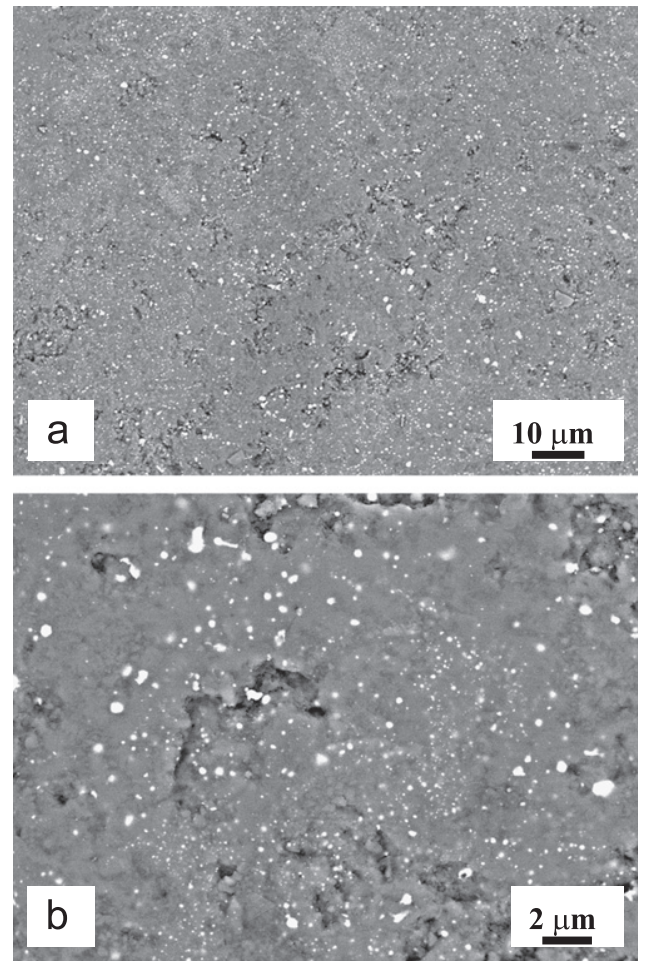

Fig. 4. Typical FESEM images (back-scattered electron images in chemical contrast mode) of the polished surface of the C1000RS CNT$\mathrm{Fe}-$ mullite specimen. C1100RS is similar.

estimated to be about $4 \mathrm{wt} \%$. The carbon content in the $\mathrm{C} 1000 \mathrm{R}$ and $\mathrm{C} 1100 \mathrm{R}$ powders is 2.3 and $3.0 \mathrm{wt} \%$, respectively. The specific surface areas are similar to each other (6.1 and $6.2 \mathrm{~m}^{2} / \mathrm{g}$, respectively). These values are slightly higher than those found for the corresponding catalytic materials. As pointed out earlier [16], the deposition of carbon in the composite powder, notably in the form of CNTs, is responsible for most of this additional surface area. Low-magnification FESEM images [13] revealed that the mullite grains, several tens of micrometers in size, are fairly irregularly shaped. High-magnification FESEM images of C1000R (Fig. 1) and C1100R (Fig. 2) show long and flexible filaments homogeneously covering the surface of the mullite grains (Figs. 1a, b and 2a). The surface of the filaments is smooth and regular, their diameter is lower than $30 \mathrm{~nm}$ and their length is of the order of a few tens of micrometers (Fig. 1b-d). From earlier results, it is known that such filaments are isolated
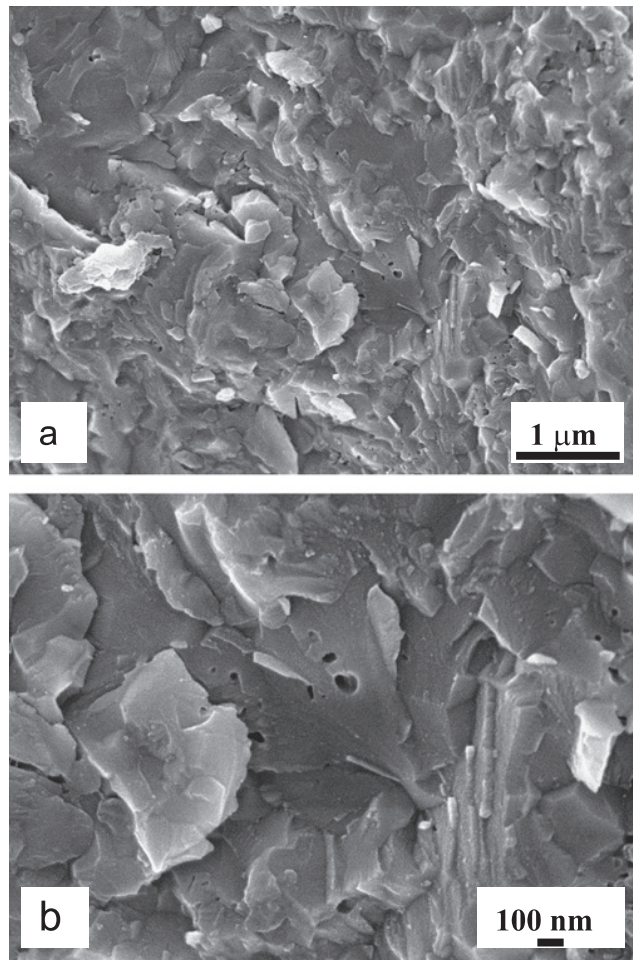

Fig. 5. Typical FESEM images of the fracture surface of the mullite specimen.

CNTs and/or CNTs bundles. For both powders, but more so for C1100R, some grains are covered by a mixture of CNTs and carbon nanofibers, which are easily detectable because their surface is rough and their diameter is in the range 30-80 nm (Fig. 2b-d). High-resolution transmission electron microscopy images [13] revealed that the CNTs are mostly double-walled and few-walled (3-6 walls).

\subsection{Sintered specimens}

Analysis of the XRD patterns of the composite pellets (Fig. 3) reveals that mullite is the major oxide phase, whereas the peaks for corundum are less intense than for the corresponding powders. No hercynite is detected, showing that the totality of hercynite and part of corundum have been dissolved into mullite upon the increase in temperature up to $1500{ }^{\circ} \mathrm{C}$ during SPS. The (110) $\alpha$-Fe peak is more intense and narrower than it was for the 

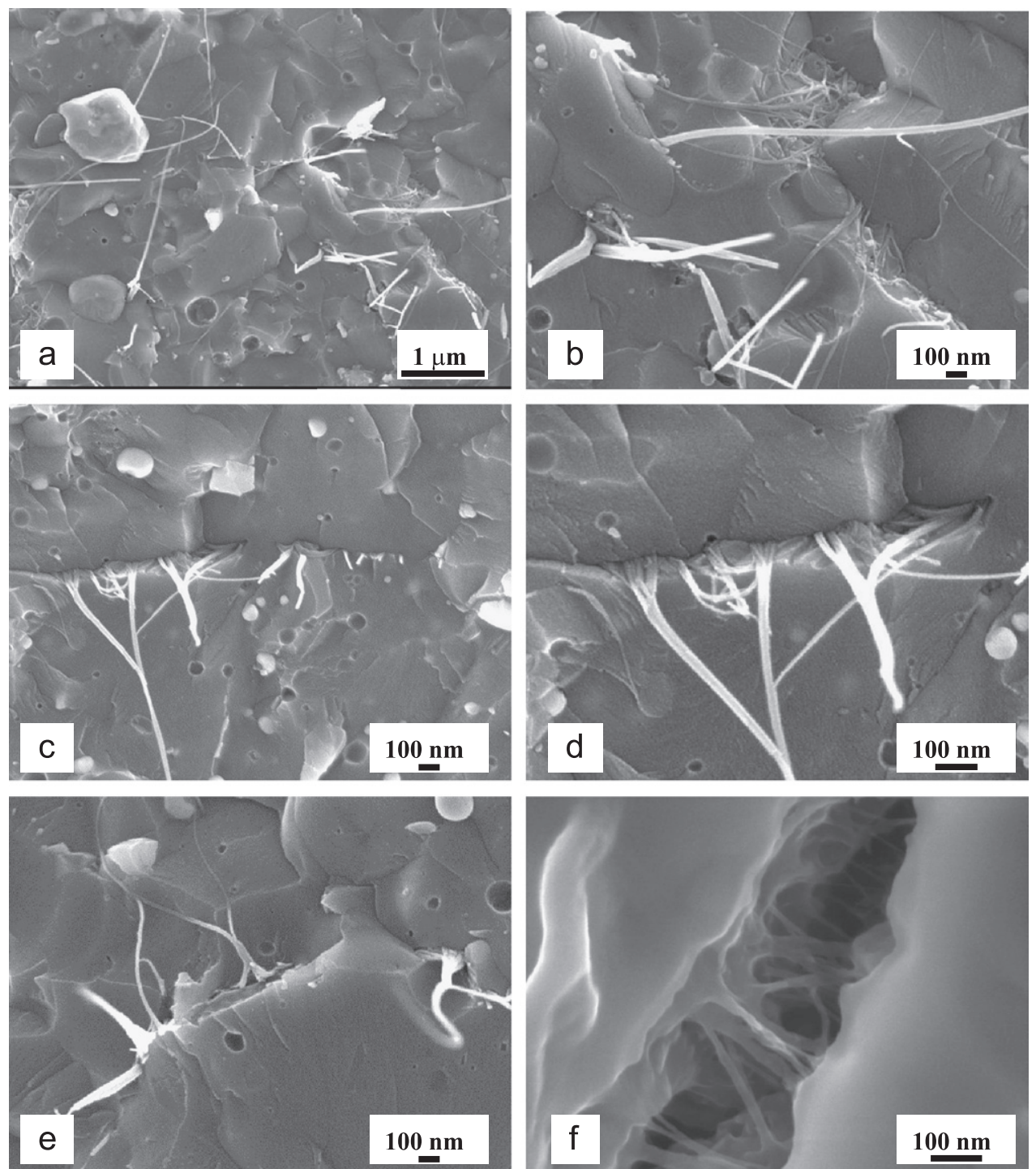

Fig. 6. Typical FESEM images of the fracture surface of the CNT-Fe-mullite specimens.

powders, reflecting the growth of the $\mathrm{Fe}$ crystallites. The density evaluated by the Archimedes method is equal to 3.09, 3.21 and 3.16 for the mullite, C1000RS and C1100RS specimens, respectively. The relative density is difficult to calculate because there is too much uncertainty on the actual composition of the materials. The electrical conductivity, Vickers microhardness, fracture strength and toughness are reported in Table 1 . The electrical conductivity of the mullite pellet is lower than $10^{-13} \mathrm{~S} / \mathrm{cm}$ but cannot be given with precision, because the measured resistance value was the detection limit of the equipment. For both C1000RS and C1100RS, the electrical conductivity is $2.4 \pm 0.2 \mathrm{~S} / \mathrm{cm}$, which could indicate that the CNTs are mostly undamaged using the present SPS conditions, as confirmed by FESEM observations presented later in this study. The Vickers microhardness of C1000RS (14.2 GPa) and C1100RS $(13.5 \mathrm{GPa})$ are lower than that of mullite $(15.1 \mathrm{GPa})$. The fracture strength values for pure mullite and both composites (about $240 \mathrm{MPa}$ ) are lower than the values reported by Wang et al. [12] for pure mullite and a $3 \mathrm{wt} \%$ CNT-mullite composite (384 and $432 \mathrm{MPa}$, respectively) prepared by hot-pressing at the same temperature than our samples $\left(1500^{\circ} \mathrm{C}\right)$ and reported to have reached full density. Note that the measured densities were not reported in [12] and therefore it is difficult to compare with the present data. For mullite, it is reported [12] that fracture strength is increased when increasing the hot-pressing temperature to 1600 and $1650{ }^{\circ} \mathrm{C}$ (466 and $443 \mathrm{MPa}$, respectively). For the composites, fracture strength is increased when increasing the hot-pressing temperature to $1600{ }^{\circ} \mathrm{C}(512 \mathrm{MPa})$ despite achieving a lower relative density $(96 \%)$ whereas it is markedly lower (302 MPa) upon a further increase to $1650{ }^{\circ} \mathrm{C}$, which is thought [12] to reflect a still lower relative density $(<94 \%)$ and fewer numbers of pullout MWNTs. This could in turn reflect that the CNTs were damaged upon hot-pressing at $1650{ }^{\circ} \mathrm{C}$. Indeed, comparing hot-pressing and SPS revealed that the former technique cause much more damage to the CNTS, possibly because of the longer times 

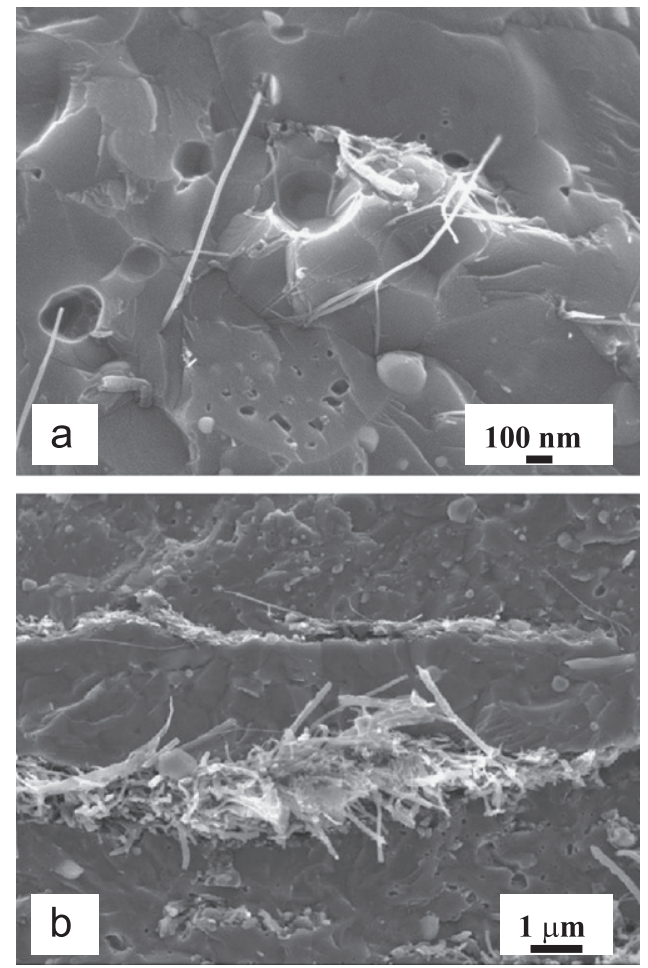

Fig. 7. Typical FESEM images of the fracture surface of the C1000RS and C1100RS CNT-Fe-mullite specimens showing undesirable carbon nanofibers (a) and bundles agglomerates at the grain boundaries (b).

involved [7,17]. The toughness for C1000RS (3.3 MPa ${ }^{1 / 2}$ ) is significantly higher than the values reported [12] for pure mullite and a $3 \mathrm{wt} \%$ CNT-mullite composite hot-pressed at $1500{ }^{\circ} \mathrm{C}\left(1.72\right.$ and $2.91 \mathrm{MPa} \mathrm{m}^{1 / 2}$, respectively). It is similar to the values reported for the composites hot-pressed at 1550 and $1600{ }^{\circ} \mathrm{C}$ (3.27 and $3.60 \mathrm{MPa} \mathrm{m}^{1 / 2}$, respectively). For C1100RS, the toughness $\left(2.8 \mathrm{MPa} \mathrm{m}^{1 / 2}\right)$ is lower than for C1000RS, which could be due to the presence of carbon nanofibers. FESEM images (back-scattered electron images in chemical contrast mode) of the polished surface of C1000RS (Fig. 4) show the presence of some residual porosity, which could contribute to the low fracture strength. The Fe particles (appearing as white dots in the images) are fairly homogeneously dispersed and their diameter is in the range about $50 \mathrm{~nm}$ to $1 \mu \mathrm{m}$, most of them being however smaller than $200 \mathrm{~nm}$. C1100RS (images not shown) is very similar to C1000RS. The possible role of the Fe particles on the mechanical properties is fairly complex. Indeed, it was proposed that a low $\mathrm{Fe}$ content favors strengthening whereas a high $\mathrm{Fe}$ content favors a moderate toughening [18]. This warrants further studies. FESEM images of the fracture surface of mullite (Fig. 5) and the composites (Fig. 6) show that the fracture is mostly transgranular although some intergranular fracture is also observed. Some residual porosity is observed in all specimens. Note however that round holes such as those observed in Fig. 6c are the original locations of $\mathrm{Fe}$ particles that happened to remain on the other (unobserved) side of the fracture. The CNTs appear to be undamaged. Some CNT bundles are cut near the matrix grain surface but some are protruding from the surface, suggesting some degree of bundle pullout (Fig. 6a). CNT bundles emerging from the matrix grain boundaries are also observed (Fig. 6b-e). Interestingly, large-scale crack-bridging is observed (Fig. 6f) in a crack about $300-500 \mathrm{~nm}$ wide, as shown in earlier studies on DWCNT- $\mathrm{Al}_{2} \mathrm{O}_{3}[6]$ and DWCNT- $\mathrm{MgO}$ composites [19]. Most CNTs appear to be taught, i.e. under tensile stress. It is thus probable that they directly contribute to the reinforcement. Carbon nanofibers (Fig. 7a) and excessive amounts of bundles agglomerated at the grain boundaries (Fig. 7b) are also observed. The latter could act as cracks and limit the cohesion and strength of the matrix grain boundaries. However, this is not widespread in the material, as evidenced by the mainly transgranular fracture mode, and could probably be avoided if the $\mathrm{Fe}_{0.6} \mathrm{Al}_{5.4} \mathrm{Si}_{2} \mathrm{O}_{13}$ powders were ball-milled or attrition-milled in order to decrease the grain size, prior to the reduction step. This would favor a better distribution of the CNTs around the mullite grains when they are formed in situ during the CCVD treatment.

\section{Conclusions}

The SENB toughness of a CNT-Fe-mullite nanocomposite consolidated by SPS is twice than the one for unreinforced mullite ( 3.3 vs. $1.6 \mathrm{MPa} \mathrm{m}^{1 / 2}$ ). The mechanisms of crack-bridging by the CNTs and CNT bundle pullout have been evidenced. The electrical conductivity of the nanocomposites is $2.4 \mathrm{~S} / \mathrm{cm}$ whereas mullite is insulating. The CNTs, mostly double- and few-walled (3-6 walls), appear to be undamaged and are fairly homogeneously dispersed at the mullite grain boundaries. These results arise because of the unique microstructure achieved through the use of an in situ route obviating any milling step for the synthesis of composite powders and through consolidation by SPS. However, carbon nanofibers and bundles agglomerated at the grain boundaries are also observed in some areas and weaken the materials. Therefore, reducing the matrix grain size to obtain a better CNT dispersion will be the subject of future work. The possible role of the Fe particles on the mechanical properties also warrants further studies.

\section{Acknowledgments}

SPS was performed at the Plateforme Nationale CNRS de Frittage-Flash ( $\mathrm{PNF}^{2}$, Toulouse). FESEM was performed at TEMSCAN, the "Service Commun de Microscopie Electronique", Université Paul-Sabatier.

\section{References}

[1] M.M.J. Treacy, T.W. Ebbesen, J.M. Gibson, Exceptionally high Young's modulus observed for individual carbon nanotubes, Nature 381 (1996) 678-680. 
[2] M.F. Yu, O. Lourie, M.J. Dyer, K. Moloni, T.F. Kelly, R.S. Ruoff, Strength and breaking mechanism of multiwalled carbon nanotubes under tensile load, Science 287 (2000) 637-640.

[3] Y. Ando, X. Zhao, H. Shimoyama, G. Sakai, K. Kaneto, Physical properties of multiwalled carbon nanotubes, International Journal of Inorganic Materials 1 (1999) 77-82.

[4] M.J. Biercuk, M.C. Llaguno, M. Radosavlijevic, J.K. Hyun, A.T. Johnson, Carbon nanotube composites for thermal management, Applied Physics Letters 80 (2002) 2767-2769.

[5] J. Cho, A.R. Boccaccini, M.S.P. Shaffer, Ceramic matrix composites containing carbon nanotubes, Journal of Materials Science 44 (2009) 1934-1951.

[6] E. Zapata-Solvas, D. Gomez-Garcia, A. Dominguez-Rodriguez, Towards physical properties tailoring of carbon nanotubesreinforced ceramic matrix composites, Journal of European Ceramic Society 32 (2012) 3001-3020.

[7] A. Peigney, S. Rul, F. Lefèvre-Schlick, Ch. Laurent, Densification during hot-pressing of carbon nanotube-metal-magnesium aluminate spinel nanocomposites, Journal of European Ceramic Society 27 (2007) 2183-2193.

[8] E. Flahaut, A. Peigney, Ch. Laurent, Ch. Marlière, F. Chastel, A. Rousset, Carbon nanotube-metal-oxide nanocomposites: microstructure, electrical conductivity and mechanical properties, Acta Materialia 48 (2000) 3803-3812.

[9] W.A. Curtin, B.W. Sheldon, CNT-reinforced ceramics and metals, Materials Today 7 (2004) 44-49.

[10] A. Kasperski, A. Weibel, C. Estournès, Ch. Laurent, A. Peigney, Preparation-microstructure-property relationships in double-walled carbon nanotubes/alumina composites, Carbon, 53 (2013) 62-72.

[11] H. Schneider, J. Schreuer, B. Hildmann, Structure and properties of mullite-review, Journal of European Ceramic Society 28 (2008) $329-344$.
[12] J. Wang, H. Kou, X. Liu, Y. Pan, J. Guo, Reinforcement of mullite matrix with multi-walled carbon nanotubes, Ceramics International 33 (2007) 719-722.

[13] V.G. de Resende, Xu Hui, Ch. Laurent, A. Weibel, E. De Grave, A. Peigney, Fe-substituted mullite powders for the in-situ synthesis of carbon nanotubes by catalytic chemical vapor deposition, Journal of Physical Chemistry C 113 (2009) 11239-11245.

[14] K.C. Patil, Advanced ceramics combustion synthesis and properties, Bulletin of Materials Science 16 (1993) 533-541.

[15] W.F. Brown, J.E. Srawley, Plane strain crack toughness testing of high strength metallic materials, ASTM Special Technical Publication, American Society for Testing and Materials, Philadelphia, 1966, p. 410 .

[16] A. Peigney, Ch. Laurent, F. Dobigeon, A. Rousset, Carbon nanotubes grown in-situ by a novel catalytic method, Journal of Materials Research 12 (1997) 613-615.

[17] F. Legorreta Garcia, C. Estournès, A. Peigney, A. Weibel, E. Flahaut, Ch. Laurent, Carbon nanotube-magnesia nanocomposites by spark-plasma-sintering: microstructure, electrical conductivity and microhardness, Scripta Materialia 60 (2009) 741-744.

[18] H. Wang, T. Sekino, T. Kusunose, T. Nakayama, K. Niihara, Properties and microstructure of mullite-based iron nanocomposite, Key Engineering Materials 317-318 (2006) 611-614.

[19] A. Peigney, F. Legorreta Garcia, C. Estournès, A. Weibel, Ch. Laurent, Toughening and hardening in double-walled carbon nanotube/nanostructured magnesia composites, Carbon 48 (2010) 1952-1960. 